\title{
SPOTLIGHT
}

\section{Contraction and convergence: the best possible solution to the twin problems of climate change and inequity}

"Philosophers have only interpreted the world; the point is to change it." Karl Marx, 1845

\author{
Robin Stott co-chair of the Climate and Health Council
}

c/o BMJ Publishing Group, Tavistock Square, London WC1 H9JR

\begin{abstract}
Much is now known about anthropogenically induced climate change, its impacts on the planet's species, and the need for urgent action to avoid catastrophe. ${ }^{12}$ The unequal distribution of resources between the materially rich and the materially poor amplifies the multiple adverse effects of climate change, so disrupting ecosystems, reducing agricultural productivity, and displacing populations. ${ }^{3}$

The consequences differ for rich and poor populations. In poor countries, life expectancy may be only 40 years (Swaziland and Mozambique), infant mortality as high as 180 in 1000 (Angola), and the lifetime risk of dying in childbirth 1 in 16 (sub-Saharan Africa). In rich countries, life expectancy can exceed 82 years, infant mortality can be as low as 4 in 1000, and the lifetime risk of dying in childbirth is less than 1 in 3000 . But, having reaped the health benefits of wealth, these countries now face the diseases of excess. In the United States $30 \%$ of the population is obese, for example, and in urban Samoa a staggering 70\%, and with obesity comes an increasing prevalence of diabetes, cardiovascular disease, musculoskeletal problems, ${ }^{4}$ and rocketing healthcare costs. And despite their affluence, over $10 \%$ of many rich populations are on antidepressants. ${ }^{5}$
\end{abstract}

Despite these different disease patterns, most early deaths and many disabilities are preventable. We know what to do: improve the conditions in which people are born, grow, live, work, and age. This improvement entails tackling the structural drivers of these conditions: inequities in power, money, and resources. ${ }^{6}$ Fortunately, many of the measures needed to improve global health are the same as those needed to make the required $80 \%$ reduction in global greenhouse gas emissions. What is good for tackling climate change is good for health, and responding to climate change is not a distraction from the business of protecting health.

Protection of public health is the duty to society of health professionals. Their actions are rooted in the ethical obligation to create the best possible circumstances that enable humanity to flourish and be healthy. Many influential health professional bodies and individuals now recognise that if climate change is tackled in a fair and just way, the health of all will be transformed. ${ }^{7}$ Solutions are available that health professionals must vigorously promote, particularly as the global response to date has been woefully inadequate: despite numerous global meetings committed to their reduction, carbon dioxide emissions have risen by $45 \%$ since $1990 .^{8}$

\section{What needs to be done?}

Many local initiatives are responding to the challenge. In 1991 Germany, for example, introduced a feed-in tariff, an amount of money paid by the government or utility provider for energy produced by a renewable energy producer. Consequently, 20\% of Germany's energy is renewable and about 340000 people work in the renewable energy sector, which has a turnover of $€ 8.7 \mathrm{bn}(£ 7.3 \mathrm{bn} ; \$ 11.6 \mathrm{bn})$ and in 2005 there was a reduction in $\mathrm{CO}_{2}$ emissions of 38 million tonnes attributable to German legislation. ${ }^{9}$ UK retailer Marks and Spencer is well on the way to becoming the world's most sustainable major retailer, achieving by 2015 all the 180 sustainability goals set out in its Plan A. ${ }^{10}$ Wangari Maathai received the 2004 Nobel peace prize for her role in inspiring 80000 women in her native Kenya to plant 30 million indigenous trees; a project giving many Kenyan women purpose, companionship, and a source of income, as well as capturing carbon dioxide. $\Downarrow$

Iran has reduced its fertility rate from an average of 6.54 in 1986 to 1.8 in 2008 , through policies enabling $80 \%$ of women to get secondary education, and easy access to family planning. ${ }^{11}$

Individuals, communities, and governments have created environments where these initiatives can take root and flourish. These locally created environments are isolated, however, as most of the world continues to set economic growth as the marker of progress - the precise cause of our current predicament. 
Any solution has to refashion the prevailing global environment and create the circumstances for new so called virtuous projects to thrive. Virtuous projects need three ingredients to enable small scale local activity and yet to be global in reach.

Firstly, a scientifically assessed and globally binding commitment to cap and reduce carbon emissions is needed.

Secondly, a mechanism is needed to ensure that resources are transferred to those countries where both living standards and fossil fuel use have been low. These resources must be sufficient to cover the $\$ 110$ per person per year that Jeffrey Sachs concludes is the minimum to enable low income countries to reach the Millennium Development Goals. ${ }^{12} 1314$ The attainment of these goals is essential for health; providing universal access to female education and reproductive health services is a well tested route to stabilising population numbers. ${ }^{12}$

And thirdly, an approach to development is needed that gives financial power to individuals and local communities, and provides the incentive to make low carbon choices.

\section{Contraction and convergence}

The most feasible present framework that embraces these principles is contraction and convergence $(\mathrm{C} \& \mathrm{C}) .{ }^{15} \mathrm{C} \& \mathrm{C}$ is based on the science of limits and the logic of global rights. The global total of permitted emissions is calculated so as to achieve the objective of limiting and stabilising atmospheric carbon concentrations below the level beyond which runaway climate change becomes unavoidable (presently thought to be about 400 parts per million). This calculated amount of carbon (the global carbon budget) provides the quantum from which an inclusive, global, equal rights per capita entitlement of carbon is derived; an entitlement that will go to each adult. Emissions trading can then take place within the context of this scientifically calculated carbon budget and the rights based mechanism for distribution.

The implementation of a framework founded on these principles will require tough negotiation, particularly around the speed of convergence to an equal per capita entitlement of carbon dioxide emissions, which can be no more than one and a half tonnes per person by 2050 (assuming a global population of 9 billion). Calculation of the initial carbon budget takes account of the present capacity of the global sinks: the oceans, soils, forests, and other flora that absorb $\mathrm{CO}_{2}$. If these sinks diminish, $\mathrm{C} \& \mathrm{C}$ enables the necessary recalculation; the contraction and convergence framework has the capacity to be modified in relation to evolving risks.

\section{How will C\&C work?}

The equal per capita entitlement of carbon emissions can be pre-distributed as carbon coupons to consumers who could then negotiate the sale of these coupons. Under-consumers (generally the poor) will have coupons to sell to over-consumers (generally the rich). Market forces will work for the poor as well as to reduce carbon emissions; a key feature of the scheme. Putting the poor in control is a crucial development goal, as evidenced by the recent moves by donor agencies such as the International Red Cross to simply give cash to the poor. Recent publications testify to the efficacy of this approach. ${ }^{16}{ }^{17}$

Equal entitlement under $\mathrm{C} \& \mathrm{C}$ has the added advantage that, in the early stages of the implementation of the framework, rapidly industrialising countries such as China, India, and Brazil (which are still relatively low per capita emitters of carbon) will be beneficiaries.
Credits (entitlements) will be issued by the global institution that oversees global sustainable development and agrees and implements C\&C. C\&C envisages that a greater portion of these entitlements are delivered to individuals or small collectives. This commitment can be written into the global agreements. So also can the proportion of the entitlements that would be held by the country level group to cover communal facilities such as schools and hospitals. For instance, in the UK, the proportion of carbon emitted by collective rather than individual actions is around $40 \%$, an indication of the proportion of entitlements that the UK would hold centrally.

The widespread uptake of microcredit and the penetration of electronic communication, especially mobile phone technology, provides a route for implementing $\mathrm{C} \& \mathrm{C}$ in poorer countries. And although $\mathrm{C} \& \mathrm{C}$ encourages low carbon solutions, it does not seek to define those solutions for any particular group. The agency of individuals and communities to use resources as they think best makes $\mathrm{C} \& \mathrm{C}$ nonintrusive and is one of the socially attractive properties of the scheme.

No other framework quantifies allowable carbon emissions against an atmospheric $\mathrm{CO}_{2}$ concentration. No other framework allocates entitlements of this amount in a way which is to the advantage of underprivileged people in both the countries that are yet to industrialise and the rapidly industrialising countries. These unique features account for the significant level of global support for $\mathrm{C} \& \mathrm{C}$, support which will be essential to getting the framework implemented. ${ }^{15}{ }^{18}$ During the implementation of $\mathrm{C} \& \mathrm{C}$, a period of no more than a few years, a low carbon development fund of at least $\$ 150 \mathrm{bn}$ must immediately be established. Much of the money could be raised by a tax on airline tickets and imposition of a $\$ 5$ tax on each of the 20 billion barrels of oil used by OECD countries each year, or through the introduction of a financial transaction tax as advocated by Nobel prize winning economist James Tobin. ${ }^{19} 20$

Time is of the essence. This is well understood by health professionals. After any serious trauma, a patient's chances of recovery are much greater if treatment is started within one hour of the event: the so called golden hour. Our traumatised globe is nearing the end of its golden hour. For the sake of present and future generations, we have to move quickly for our interventions to successfully heal the globe. An agreement to implement $\mathrm{C} \& \mathrm{C}$ cannot be delayed.

RS has studied, written, and spoken extensively on the health impacts of climate change for the past 20 years. He is particularly interested in the co-benefits to health of implementing a fair shares solution to climate change. RS is guarantor.

The author has completed the ICMJE uniform disclosure form at www. icmje.org/coi_disclosure.pdf (available on request from the corresponding author) and declares no support from any organisation for the submitted work; no financial relationships with any organisations that might have an interest in the submitted work in the previous three years; no other relationships or activities that could appear to have influenced the submitted work.

Provenance and peer review: Commissioned; not externally peer reviewed.

\footnotetext{
Intergovernmental Panel on Climate Change (IPCC). IPCC Fourth assessment report: climate change 2007 (AR4). Cambridge University Press, 2007.

2 WHO. Climate change and health. Fact sheet no 266. January 2010. www.who.int mediacentre/factsheets/fs266/en.

3 WHO, Commission on Social Determinants of Health. Closing the gap in a generation: health equity through action on the social determinants of health. Final report of the Commission on Social Determinants of Health. WHO, 2008. www.who.int/social_ determinants/thecommission/finalreport/en/index.html.

4 WHO. Global status report on non-communicable diseases 2010. WHO, 2011. www. who int/nmh/publications/ncd report2010/en.
} 
5 Fox M. Antidepressant use doubles in the United States, study finds. 2009. www. worldwideinfoforum.com/forums/antidepressant use_doubles_html.

6 UCL Institute of Health Equity. Strategic review of health inequalities in England post-2010 (The Marmot Review). February 2010. www.instituteofhealthequity.org.

7 Lancet. Health and climate change series. www.thelancet.com/series/health-and-climatechange.

8 European Commission, Joint Research Centre (JRC). Steep increase in global $\mathrm{CO} 2$ emissions despite reductions by industrialized countries with binding Kyoto targets. ScienceDaily. 21 September 2011. www.sciencedaily.com/releases/2011/09/ $110921074750 . \mathrm{htm}$.

9 Wenzel B. What electricity from renewable energies costs (abridged version). Federal Ministry for the Environment, Nature Conservation and Nuclear Safety (BMU), Public Relations Division, Berlin. February 2006. www.oregon.gov/ENERGY/RENEW/docs/ Germany electricity costs 2006.pdf.

10 Marks \& Spencer. Plan A. plana.marksandspencer.com.

11 Trading Economics. World Bank data. Fertility rate; total (births per woman) in Iran. www. tradingeconomics.com/iran/fertility-rate-total-births-per-woman-wb-data.html.

12 Sachs J. Can extreme poverty be eliminated? Scientific American 22 August 2005

13 Millennium Villages. Overview. www.millenniumvillages.org/files/2011/02/MVInfokit_rev17. pdf.
14 Bunting M. Havens of hope: the Ugandan villages on target to meet millennium development goals. The Guardian 2009 May 27. www.guardian.co.uk/katine/2009/may/ 27/uganda-millennium-village.

15 Global Commons Institute. Contraction and convergence. www.gci.org.uk.

16 Hanlon J, Barrientos A, Hulme D. Just give money to the poor: the development revolution from the global south. Kumarian Press, 2010

17 Farrington J, Harvey P, Slater R. Cash transfers in the context of pro-poor growth. OECD. July 2005. www.oecd.org/dataoecd/33/58/36570713.pdf.

18 Global Commons Institute, C\&C Foundation. www.candcfoundation.com.

19 Center for Environmental Economic Development (CEED), Tobin Tax Initiative. Fact sheet on Tobin Taxes. www.ceedweb.org/iirp/factsheet.htm.

20 Sandbu M. The Tobin Tax explained. Financial Times 2011 Sep 28

Accepted: 24 February 2012

Cite this as: BMJ 2012;344:e1765

(c) BMJ Publishing Group Ltd 2012 


\section{Figure}

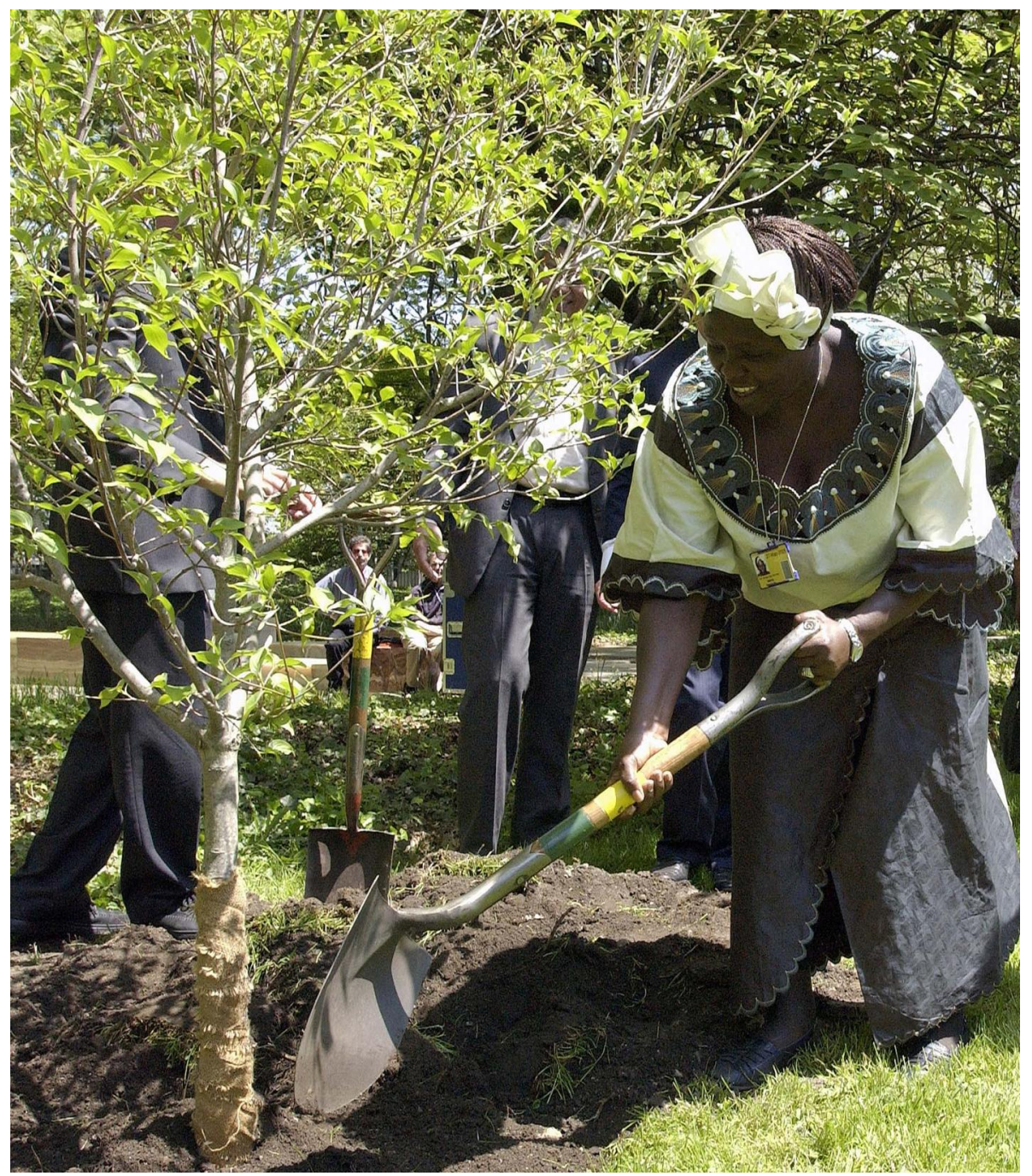

